\title{
Genomic instability related to zinc deficiency and excess in an in vitro model: is the upper estimate of the physiological requirements recommended for children safe?
}

\author{
Gisel Padula $^{1,2}$ - María Virginia Ponzinibbio ${ }^{1}$ - Rocío Celeste Gambaro ${ }^{1}$. \\ Analía Isabel Seoane ${ }^{1}$
}

Received: 7 December 2016 / Accepted: 13 March 2017 /Published online: 26 May 2017 / Editor: Tetsuji Okamoto.

(C) The Society for In Vitro Biology 2017

\begin{abstract}
Micronutrients are important for the prevention of degenerative diseases due to their role in maintaining genomic stability. Therefore, there is international concern about the need to redefine the optimal mineral and vitamin requirements to prevent DNA damage. We analyzed the cytostatic, cytotoxic, and genotoxic effect of in vitro zinc supplementation to determine the effects of zinc deficiency and excess and whether the upper estimate of the physiological requirement recommended for children is safe. To achieve zinc deficiency, DMEM/Ham's F12 medium (HF12) was chelated (HF12Q). Lymphocytes were isolated from healthy female donors (age range, 5-10 yr) and cultured for $7 \mathrm{~d}$ as follows: negative control (HF12, $60 \mu \mathrm{g} / \mathrm{dl} \mathrm{ZnSO}_{4}$ ); deficient (HF12Q, $12 \mu \mathrm{g} / \mathrm{dl}$ $\left.\mathrm{ZnSO}_{4}\right)$; lower level ( $\left.\mathrm{HF} 12 \mathrm{Q}+80 \mu \mathrm{g} / \mathrm{dl} \mathrm{ZnSO}_{4}\right)$; average level (HF12Q + $180 \mu \mathrm{g} / \mathrm{dl} \mathrm{ZnSO} 4)$; upper limit (HF12Q + $280 \mu \mathrm{g} / \mathrm{dl} \mathrm{ZnSO})_{4}$ ); and excess (HF12Q $+380 \mu \mathrm{g} / \mathrm{dl} \mathrm{ZnSO}_{4}$ ). The comet (quantitative analysis) and cytokinesis-block micronucleus cytome assays were used. Differences were evaluated with Kruskal-Wallis and ANOVA $(p<0.05)$. Olive tail moment, tail length, micronuclei frequency, and apoptotic and necrotic percentages were significantly higher in the deficient, upper limit, and excess cultures compared with the negative control, lower, and average limit ones. In vitro zinc supplementation at the lower and average limit $(80$ and $180 \mu \mathrm{g} / \mathrm{dl}$
\end{abstract}

Gisel Padula

giselpadula@conicet.gov.ar; gpadula@igevet.gob.ar

1 IGEVET - Instituto de Genética Veterinaria “Ing. Fernando Noel Dulout" (UNLP-CONICET LA PLATA), Facultad de Ciencias Veterinarias UNLP, 60 y 118 s/n, B-1900-AVW La Plata, Argentina

2 Facultad de Ciencias Naturales y Museo UNLP, 60 y 122 s/n, B-1900-AVW La Plata, Argentina
$\mathrm{ZnSO}_{4}$ ) of the physiological requirement recommended for children proved to be the most beneficial in avoiding genomic instability, whereas the deficient, upper limit, and excess (12, 280 , and $380 \mu \mathrm{g} / \mathrm{dl}$ ) cultures increased DNA and chromosomal damage and apoptotic and necrotic frequencies.

Keywords Zinc supplementation · Children · Genomic stability $\cdot$ Recommended dietary allowances $\cdot$ Health

\section{Introduction}

Argentina is presently undergoing the nutrition transition, characterized by a decrease of acute malnutrition and an increased prevalence of obesity, stunting, and hidden hunger (Lucchese et al. 2016). The World Health Organization (WHO) and the United Nations Children's Fund (UNICEF) define hidden hunger as specific vitamin and mineral deficiency. The main micronutrients required for child growth are iron, zinc $(\mathrm{Zn})$, vitamin A, vitamin B (like riboflavin), folic acid, niacin, and essential fatty acids. Micronutrient quantification is performed with the recommended dietary allowances (RDA) from the National Research Council (National Research Council Food and Nutrition Board 1989), which express the absolute value of the nutrient recommended per day.

Micronutrients are important for the prevention of degenerative diseases such as cancer, cardiovascular disease, Alzheimer's, and premature aging, due to their role in maintaining genomic stability (Fenech 2010, 2014). In human populations, genetic mutation and chromosomic aberrations may be increased by in vivo exposure to mutagenic and carcinogenic agents (Parry 1988) and by an imbalanced diet (Ames 1998). Considering that many minerals and vitamins act as substrate and/or cofactors in DNA maintenance reactions, their exact concentration in the cell is critical. Thus, non- 
optimal levels of these micronutrients would impair the activity of enzymes needed for genomic stability, since they produce DNA double or single-strand breaks, oxidative damage, or both (Fenech 2001, 2005). Therefore, there is international concern about the need to redefine the optimal mineral and vitamin requirements to prevent DNA damage. This becomes especially important for early stages of life, since the unique nutritional requirements of children make them unusually susceptible to inadequate nutrient intake.

Although severe $\mathrm{Zn}$ deficiency is not common, moderate deficiencies are relatively frequent, particularly in infancy and childhood (Hambidge 1989). This deficiency would cause a decrease in child growth and development (Roohani et al. 2013), mainly affecting height (Siklar et al. 2003; Varea et al. 2006; Grandy et al. 2010). Zn deficiency not only affects the immunological system by disturbing cell division and multiplication but also partially suppresses thymus function and decreases $\mathrm{T}$ and $\mathrm{B}$ lymphocyte proliferation and function (Haase and Rink 2009). The induction of brain growth and development alterations that cause cognitive impairments have also been reported (Prasad 2013). In this regard, the role of $\mathrm{Zn}$ in DNA synthesis and cell proliferation would account for these $\mathrm{Zn}$ deficiency-associated effects.

$\mathrm{Zn}$ is an essential component of approximately 300 proteins, such as $\mathrm{Cu} / \mathrm{Zn}$ superoxide dismutase, endonuclease IV, $\mathrm{p} 53$, and $\mathrm{Zn}$ finger proteins, such as poly ADP-ribose polymerase (PARP). It is involved in the process of genomic stability and gene expression in different ways, including the formation of chromatin structures and the participation in DNA replication and RNA transcription through transcription factors and RNA and DNA polymerases (Sharif et al. 2011, 2012). Likewise, Zn plays a key role in DNA repair (Dreosti 2001) and programmed cell death or apoptosis (Chung et al. 2005; Clegg et al. 2005; Bae et al. 2006; Chang et al. 2006).

Presently, knowledge about the optimal levels of $\mathrm{Zn}$ for genomic stability is scarce and disordered. However, there is evidence supporting the fact that marginal $\mathrm{Zn}$ deficiency impacts significantly on the percentage of spontaneous chromosome damage (Fenech 2001, 2002; Fenech and Ferguson 2001; Sharif et al. 2011, 2012). On the other hand, in vitro studies have shown that excess of different $\mathrm{Zn}$ salts, such as chromate, citrate, and sulfate, would produce a cytotoxic and genotoxic effect on different cell lines (Bae et al. 2007; Xie et al. 2009; Wise et al. 2010; Sharif et al. 2011, 2012) and laboratory animals (Tapisso et al. 2009).

Considering that $\mathrm{Zn}$ is an important micronutrient for children growth and that it is involved in the process of genomic stability, the purpose of this study was to analyze the cytostatic, cytotoxic, and genotoxic damage of in vitro $\mathrm{Zn}$ supplementation to determine the effects of Zn deficiency and excess and whether the upper estimate of the physiological requirement recommended for children is safe.

\section{Materials and Methods}

Study design In vitro modeling of peripheral blood lymphocyte cultures was used to determine the effect of micronutrients on cytotoxicity and genomic damage (Kimura et al. 2004; Wu et al. 2009; Fenech 2010). This model helps to define the optimal concentration and the safe upper limit of micronutrients (Fenech 2010). Isolated peripheral blood lymphocytes obtained from six healthy female donors (age range, 5-10 yr) were used. Written parental informed consent was obtained. This study was conducted according to the guidelines laid down in the Declaration of Helsinki and all procedures involving human subjects were approved by the Institutional Review Board of the Instituto de Desarrollo e Investigaciones Pediátricas (IDIP), La Plata Children Hospital, Buenos Aires, Argentina.

Lymphocytes were isolated with Ficoll (Histopaque ${ }^{\circledR}$ 1077 Sigma-Aldrich, St. Louis, MO) according to Fenech's protocol (2007) and cultured in $10 \mathrm{ml}$ of DMEM/Ham's F12 medium (HF12) (Sigma-Aldrich) formulated for culture without fetal bovine serum, with antibiotics (50 IU penicillin and $50 \mu \mathrm{g} / \mathrm{ml}$ streptomycin) (Bagó Laboratories, Buenos Aires, Argentina), in a humidified atmosphere with $5 \% \mathrm{CO}_{2}$. Cells were cultured in Falcon T-25 (Nunc, Denmark).

For all experiments, lymphocytes were cultured in $\mathrm{Zn}$ depleted medium (HF12Q). HF12Q was prepared with HF12 mixed with 10\% Chelex 100 (95577 Sigma) for $2 \mathrm{~h}$; the cycle of depletion was repeated for another $4 \mathrm{~h}$ (Sharif et al. 2011, 2012). Because other divalent cations $(\mathrm{Cu}, \mathrm{Fe}$, $\mathrm{Mn}$, and $\mathrm{Ca}$ ) were also chelated, we replenished the same concentration as that indicated in the formulation of the culture medium used.

In this study, $\mathrm{Zn}$ sulfate $\left(\mathrm{ZnSO}_{4}\right)$ was used to supplement cultures because of its proven higher bioavailability (Sharif et al. 2011, 2012). Three doses of $\mathrm{ZnSO}_{4}$ (Sigma-Aldrich) within the physiological requirement recommended for children $(80-280 \mu \mathrm{g} / \mathrm{dl})$ (Feliu et al. 2005) were used. Two other doses outside of such range were used to evaluate the effect of both deficiency and excess. Thus, the resulting cultures were as follows: negative control (HF12Q, $60 \mu \mathrm{g} / \mathrm{dl} \mathrm{ZnSO}_{4}$ ); deficient (HF12Q, $12 \mu \mathrm{g} / \mathrm{dl} \mathrm{ZnSO}$ ); lower level (HF12Q + $80 \mu \mathrm{g} /$ $\left.\mathrm{dl} \mathrm{ZnSO}_{4}\right)$; average level (HF12Q $\left.+180 \mu \mathrm{g} / \mathrm{dl} \mathrm{ZnSO} 4\right)$; upper limit (HF12Q + $\left.280 \mu \mathrm{g} / \mathrm{dl} \mathrm{ZnSO}_{4}\right)$; and excess (HF12Q + $380 \mu \mathrm{g} / \mathrm{dl} \mathrm{ZnSO}_{4}$ ).

Lymphocytes were cultured with $5 \% \mathrm{CO}_{2}$ at $37{ }^{\circ} \mathrm{C}$ for $7 \mathrm{~d}$ (Fenech 2010, 2014). Thereafter, $50 \mu \mathrm{l}$ was transferred to conic tubes (Eppendorf) for quantitative comet assay, and the remaining cells were used for cytokinesis-block micronucleus cytome (CBMN-Cyt) assay.

Each experimental point was set up in duplicate. Experiments were repeated three times so as to allow an accurate estimation of inter-experimental variations. 
Zn levels Atomic absorption spectrophotometry (AAS) was used to determine $\mathrm{Zn}$ levels in media before and after supplementation. Samples were diluted with trichloroacetic acid and analyzed by AAS at the Department of Physiology, National University of La Plata School of Veterinary Sciences.

Comet assay Single-cell gel electrophoresis was performed using the alkaline version described by Singh et al. (1988) with some modifications (Tice and Strauss 1995). Briefly, slides were covered with a first layer of $180 \mu \mathrm{l}$ of $0.5 \%$ normal agarose (Life Technologies, Carlsbad, CA). An amount of $75 \mu \mathrm{l}$ of $0.5 \%$ low melting point agarose (Life Technologies, Carlsbad, CA) was mixed with $25 \mu \mathrm{l}$ blood and layered onto the slides, which were immediately covered with coverslips. After agarose solidification at $4{ }^{\circ} \mathrm{C}$ for $10 \mathrm{~min}$, coverslips were removed and slides were immersed overnight at $4{ }^{\circ} \mathrm{C}$ in fresh lysis solution. The slides were equilibrated in alkaline solution for $20 \mathrm{~min}$.

Electrophoresis was carried out for $30 \mathrm{~min}$ at $25 \mathrm{~V}$ and $250 \mathrm{~mA}(1.25 \mathrm{~V} / \mathrm{cm})$. Afterwards, slides were neutralized by washing them three times with Tris buffer ( $\mathrm{pH} 7.5)$ every $5 \mathrm{~min}$, and subsequent washing in distilled water. Slides were stained with 1/1000 SYBR Green I solution (Molecular Probes, Eugene, Oregon, USA) (Olive 1999). Scoring was performed at $400 \times$ magnification using a fluorescent microscope (Olympus BX40 equipped with a 515-560 nm excitation filter) connected to a Sony 3 CCD-IRIS color video camera. DNA migration was determined with the Comet Assay Software Project (CASP) (public domain) (Końca et al. 2003). DNA damage was expressed as olive tail moment (OTM, arbitrary units) and tail length (TL, $\mu \mathrm{m})$ (Tice et al. 2000). From each of the two slides made for one experimental point, 50 randomly selected cells were measured, thus giving 100 cells per sample and 300 cells per dose in all the experiments (three determinations).

CBMN-Cyt assay Cytostatic and cytotoxic effects and chromosomal damage were assessed by the CBMN-Cyt assay according to the method of Fenech (2007) with some modifications. Briefly, after $6 \mathrm{~d}$ of culture, cytochalasin B $(3 \mu \mathrm{g} / \mathrm{ml}$ final concentration) (Sigma-Aldrich, St. Louis, MO, USA) was added for $28 \mathrm{~h}$. Samples were centrifuged and the pellet was resuspended in $5 \mathrm{ml}$ fixative 1 (sodium chloride:methanol:acetic acid 6:5:1). Cells were washed twice with fresh fixative 2 (methanol:acetic acid 5:1) and later resuspended, dropped onto clean slides and finally stained with $5 \%$ Giemsa for $10 \mathrm{~min}$. The chromosome damage biomarkers scored were micronuclei (MNi), nucleoplasmic bridges (NPBs), and nuclear buds (NBuds). One thousand binucleated cells $(\mathrm{BN})$ were analyzed per experimental point. Cytostatic effects were analyzed through the nuclear division index (NDI) and estimated by the ratio of mono-, bi-, and multinucleated cells. Five hundred viable cells were scored per experimental point to determine the frequency of cells with one, two, three, or four nuclei and calculate the NDI using the formula $\left(\mathrm{M}_{1}+2 \mathrm{M}_{2}+3 \mathrm{M}_{3}+4 \mathrm{M}_{4}\right) / \mathrm{N}$, where $\mathrm{M}_{1-4}$ represents the number of cells with $1-4$ nuclei and $\mathrm{N}$ is the total number of viable cells scored (Fenech 2007). Cytotoxicity events were assessed by the percentage of apoptotic (AC) and necrotic (NC) cells in 500 cells. Fenech's scoring criteria for MNi, NPBs, NBuds, and apoptotic and necrotic cells were used (Fenech 2007).

Statistical analysis Data are presented as means \pm standard error and $P$ values less than 0.05 were considered statistically significant. Kurtosis was estimated to determine the normal distribution of data. Quantitative comet assay results were evaluated with the nonparametric Kruskal-Wallis contrast test, which analyzes the null hypothesis of equal medians of comet parameters within each of the four treatments. Results of the CBMN-Cyt assay were statistically analyzed by simple ANOVA and multiple range test. Statgraphics ${ }^{\circledR} 5.1$ software (Manugistics Inc., Rockville, MD) was used for all the analyses.

\section{Results}

The mineral level before and after $\mathrm{ZnSO}_{4}$ supplementation is presented in Table 1.

DNA strand breaks and alkali labile sites were determined with the comet assay (Fig. 1). OTM and TL quantitative analysis results were statistically significant $(p<0.001)$. In the case of OTM, the Kruskal-Wallis test showed statistically significant differences for almost all comparisons, excepting negative control with $80 \mu \mathrm{g} / \mathrm{dl} \mathrm{ZnSO}_{4}$ and control with $180 \mu \mathrm{g} / \mathrm{dl}$ $\mathrm{ZnSO}_{4}$. OTM was significantly higher in the deficient, 280

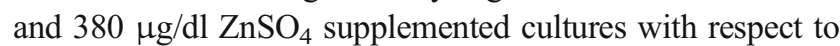
the negative control, 80 , and $180 \mu \mathrm{g} / \mathrm{dl} \mathrm{ZnSO}_{4}$ supplemented ones $(p<0.001)$. Cultures supplemented with 80 and $180 \mu \mathrm{g} /$ $\mathrm{dl} \mathrm{ZnSO}_{4}$ had the lowest OTM. Similar results were obtained for TL (negative control vs. deficient and negative control vs. $380 \mu \mathrm{g} / \mathrm{dl} \mathrm{ZnSO}_{4} p<0.001$; negative control vs. $280 \mu \mathrm{g} / \mathrm{dl}$ $\mathrm{ZnSO}_{4} p<0.01$ ).

Table 2 shows the results obtained with the CBMN-Cyt assay. The cytotoxic effect evaluated with NDI decreased in deficient cultures as well as in those supplemented with 280 and $380 \mu \mathrm{g} / \mathrm{dl} \mathrm{ZnSO}_{4}$. The highest NDI was observed in 80 and $180 \mu \mathrm{g} / \mathrm{dl} \mathrm{ZnSO}_{4}$ cultures. However, none of the differences observed resulted statistically significant. Assessment of cytotoxic effects with AC and NC percentages in 500 cells by the analysis of variance showed statistically significant differences among treatments $(p<0.001)$. No differences were found among the negative control, 80 , and $180 \mu \mathrm{g} / \mathrm{dl}$ $\mathrm{ZnSO}_{4}$ cultures. The highest $\mathrm{AC}$ and $\mathrm{NC}$ percentage was observed in the deficient and $380 \mu \mathrm{g} / \mathrm{dl} \mathrm{ZnSO}_{4}$ cultures. On the other hand, the $280 \mu \mathrm{g} / \mathrm{dl} \mathrm{ZnSO}_{4}$ supplemented culture 
Table 1. Mineral level before and after supplementation with $\mathrm{ZnSO}_{4}$

Culture $\quad \mathrm{ZnSO}_{4}$ level $(\mu \mathrm{g} / \mathrm{dl})$

\begin{tabular}{lll}
\cline { 2 - 3 } & Before & After \\
\hline Negative control & $60.08 \pm 0.00017$ & $60.08 \pm 0.00017$ \\
Deficient & $12.18 \pm 0.0004$ & $12.18 \pm 0.0004$ \\
Lower level & $12.18 \pm 0.0004$ & $80.05 \pm 0.0001$ \\
Average level & $12.18 \pm 0.0004$ & $180.03 \pm 0.00009$ \\
Upper limit & $12.18 \pm 0.0004$ & $280.06 \pm 0.0001$ \\
Excess & $12.18 \pm 0.0004$ & $380.01 \pm 0.00003$ \\
\hline
\end{tabular}

presented higher $\mathrm{AC}$ and $\mathrm{NC}$ percentages than the negative control, 80, and $180 \mu \mathrm{g} / \mathrm{dl} \mathrm{ZnSO}_{4}$ supplemented ones. Chromosome damage evaluation was determined by the frequency of MNi, NPBs, and NBuds in $1000 \mathrm{BN}$ cells. The analysis of variance showed statistically significant differences among treatments for MNi frequency $(p<0.001)$. Regarding the negative control, the 80 , and the $180 \mu \mathrm{g} / \mathrm{dl}$ $\mathrm{ZnSO}_{4}$ cultures, no significant differences could be detected with the multiple range test. For this marker, the highest MNi frequency was observed in the $380 \mu \mathrm{g} / \mathrm{dl} \mathrm{ZnSO}_{4}$ supplemented culture, as compared with the rest of the cultures. On the other hand, the deficient and $280 \mu \mathrm{g} / \mathrm{dl} \mathrm{ZnSO}_{4}$ supplemented cultures presented the same level of damage, markedly higher than that of the negative control, 80, and $180 \mu \mathrm{g} / \mathrm{dl} \mathrm{ZnSO}_{4}$ supplemented ones. Cultures supplemented with 80 and $180 \mu \mathrm{g} / \mathrm{dl} \mathrm{ZnSO}_{4}$ had the lower chromosome damage. Results obtained for NPBs and NBuds were mixed, showing higher but not significant values in cultures supplemented with 80 and $280 \mu \mathrm{g} / \mathrm{dl} \mathrm{ZnSO}_{4}$.

\section{Discussion}

In this study, we analyzed the cytostatic, cytotoxic, and genotoxic effect of in vitro $\mathrm{Zn}$ supplementation in order to

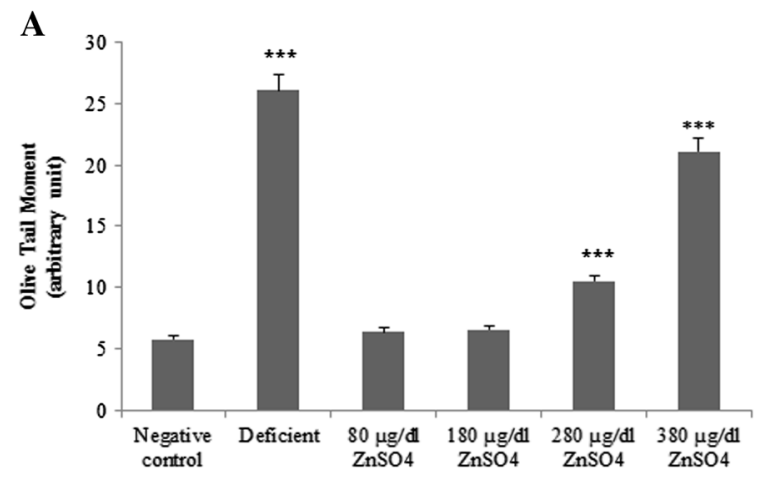

Fig. 1. Olive tail moment $(A)$ and tail length $(B)$ in peripheral lymphocytes. Data are means \pm SE. Kruskal-Wallis contrast test through the Statgraphics ${ }^{\circledR} 5.1$ software was used. Significance for the comparison determine the effects of zinc deficiency and excess and whether the upper estimate of the physiological requirement recommended for children is safe.

The effect of $\mathrm{Zn}$ deficiency and excess was analyzed with the comet and the CBMN-Cyt assays because they complement each other and provide extensive information about the possible damage induction to genetic material caused by an inadequate nutrient intake (Sharif et al. 2011).

Our results showed that $\mathrm{Zn}$ deficiency increased DNA damage. Other studies using the comet assay also reported high frequencies of DNA damage (Ho and Ames 2002; Yan et al. 2008; Song et al. 2009a, b, c). In vitro studies showed that $\mathrm{Zn}$-deficient cells present high levels of damage and failure in the DNA repair mechanisms (Dreosti 2001; Ho and Ames 2002; Yan et al. 2008; Sharif et al. 2012). In vivo studies have reported a relationship between $\mathrm{Zn}$ nutritional status and DNA damage (Bae et al. 2007; Sliwinski et al. 2009; Xie et al. 2009; Wise et al. 2010; Sharif et al. 2015). In another study carried out in men between 19 and 50 yr of age whose micronutrient intake was restricted and then reestablished, the authors recorded a significant increase of DNA breaks during the depletion period (Song et al. 2009c). Such increase reverted after $\mathrm{Zn}$ repletion, suggesting that the damage was related to the $\mathrm{Zn}$ level.

On the other hand, the increase in the frequency of DNA damage could be due to an increase in oxidative stress. There is evidence from experimental in vitro studies suggesting that addition of $\mathrm{Zn}$ protects sulfhydryl groups against oxidative damage (Bray and Bettger 1990; Sunderman 1995; Bagchi et al. 1997; Szuster-Ciesielska et al. 2000). The results from a recent intervention study (Sharif et al. 2015) showed that Zn supplementation in an elderly population with low Zn status could lower DNA damage events, hence improving genome stability, increasing antioxidant activity which may lower DNA damage risk, and increasing $\mathrm{Zn}$ storage and $\mathrm{Zn}$ uptake transporter gene expression (MT1A and ZIP1).

In the present study, supplementation with 80 and $180 \mu \mathrm{g} /$ dl Zn sulfate reduced DNA breaks with respect to the deficient

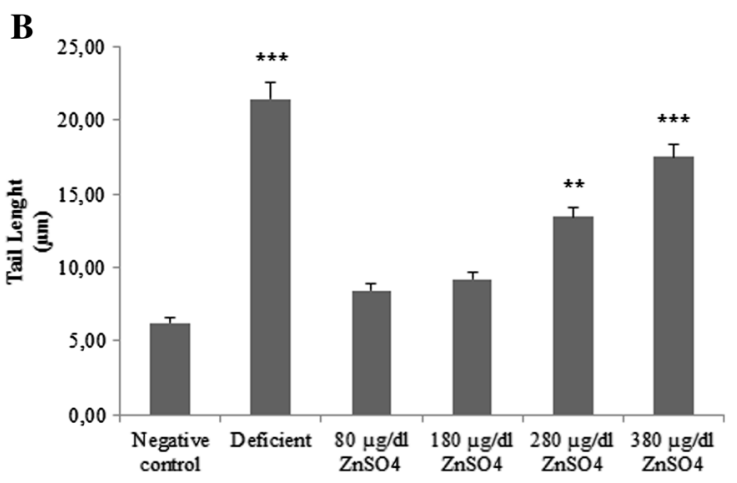

between the negative control and all the experimental points was marked with asterisks $(* * p<0.01 ; * * * p<0.001)$. 
Table 2. Nuclear division index, apoptotic cells, necrotic cells, micronuclei, nucleoplasmic bridges, and nuclear buds in peripheral lymphocytes

\begin{tabular}{|c|c|c|c|c|c|c|}
\hline \multirow[t]{2}{*}{ Culture } & \multicolumn{6}{|c|}{ CBMN-Cyt assay } \\
\hline & NDI & $\mathrm{AC} \%$ & $\mathrm{NC} \%$ & $\mathrm{MNi} \% 0$ & NPBs\%o & NBuds $\%$ \\
\hline Negative control & $1.76 \pm 0.13$ & $3.5 \pm 0.57 \mathrm{a}$ & $0.5 \pm 0.55 \mathrm{a}$ & $1.00 \pm 0.30 \mathrm{a}$ & $0.00 \pm 0.00$ & $0.00 \pm 0.00$ \\
\hline Deficient & $1.68 \pm 0.13$ & $10.5 \pm 0.57 \mathrm{c}$ & $5.5 \pm 0.58 b$ & $2.10 \pm 0.41 b$ & $2.30 \pm 0.15$ & $0.00 \pm 0.00$ \\
\hline $80 \mu \mathrm{g} / \mathrm{dl} \mathrm{ZnSO} \mathrm{Zn}_{4}$ & $1.78 \pm 0.13$ & $2.5 \pm 0.56 \mathrm{a}$ & $1.5 \pm 0.57 \mathrm{a}$ & $1.30 \pm 0.34 \mathrm{a}$ & $6.50 \pm 0.25$ & $1.00 \pm 0.10$ \\
\hline $180 \mu \mathrm{g} / \mathrm{dl} \mathrm{ZnSO}{ }_{4}$ & $1.82 \pm 0.13$ & $2.5 \pm 0.58 \mathrm{a}$ & $1.5 \pm 1.73 \mathrm{a}$ & $0.90 \pm 0.29 \mathrm{a}$ & $1.00 \pm 0.10$ & $1.00 \pm 0.10$ \\
\hline $280 \mu \mathrm{g} / \mathrm{dl} \mathrm{ZnSO}{ }_{4}$ & $1.64 \pm 0.13$ & $7.5 \pm 4.04 b$ & $3 \pm 2.31 \mathrm{a}, \mathrm{b}$ & $2.10 \pm 0.41 b$ & $10.0 \pm 0.30$ & $2.00 \pm 0.14$ \\
\hline $380 \mu \mathrm{g} / \mathrm{dl} \mathrm{ZnSO}_{4}$ & $1.52 \pm 0.12$ & $11 \pm 2.31 \mathrm{c}$ & $9 \pm 3.46 c$ & $3.20 \pm 0.47 \mathrm{c}$ & $1.00 \pm 0.10$ & $0.00 \pm 0.00$ \\
\hline
\end{tabular}

Data are means \pm SE. Groups not sharing the same letter are significantly different from each other ( $p$ values refer to ANOVA analysis: $p<0.05$ )

$N D I$ nuclear division index, $A C$ apoptotic cells, $N C$ necrotic cells, $M N$ micronuclei, $N P B$ nucleoplasmic bridges, $N B u d s$ nuclear buds

culture, whereas a high concentration $(380 \mu \mathrm{g} / \mathrm{dl})$ increased the damage, suggesting a potential genotoxic effect of excess $\mathrm{Zn}$ sulfate. Further, the upper estimate of the physiological requirements recommended for children $(280 \mu \mathrm{g} / \mathrm{dl})$ also increased DNA damage.

The results obtained with the CBMN-Cyt assay showed that both $\mathrm{Zn}$ deficiency and excess increased $\mathrm{MNi}$ frequency; in this case, the excess was more marked. Interestingly, the upper estimate of the physiological requirements recommended for children $(280 \mu \mathrm{g} / \mathrm{dl})$ was responsible for the same magnitude of chromosome damage as the deficiency. In other studies, increased MNi and NPBs frequencies in both deficiency $(0 \mu \mathrm{M})$ and excess $(32 \mu \mathrm{M})$ were observed (Sharif et al. 2011, 2012). Those works reported that all the assessed concentrations within the physiological requirements recommended for children $(4-16 \mu \mathrm{M})$ decreased such damage in both WIL2-NS and human oral keratinocyte cells. On the other hand, the higher limit of the pharmacological range $(100 \mu \mathrm{M})$ adversely affected some cell parameters (Sharif et al. 2011, 2012). By contrast, another study evaluating the effect of supplementation with $100 \mu \mathrm{M} Z \mathrm{Z}$ sulfate showed that human lymphocyte viability was not affected (Sliwinski et al. 2009). Elevated MNi frequency in lymphocytes has been shown to be associated prospectively with an increased risk of cancer in a cohort study, with severe adverse cardiovascular events in coronary artery disease patients and with mortality from cancer or cardiovascular disease in a case-control study (Milne et al. 2015).

In our study, the highest percentage of NC was observed in cultures with $\mathrm{Zn}$ excess, where chromosome damage was also the highest. A recent study suggests that excess $\mathrm{Zn}$ supplementation reduces cell viability in INS-1E rats due to increased necrosis (Nygaard et al. 2014). In vitro studies have shown that excess of other $\mathrm{Zn}$ salts, such as chromate and citrate, also caused a cytotoxic and genotoxic effect in different cell lines (Bae et al. 2007; Xie et al. 2009; Wise et al. 2010; Sharif et al. 2011) and laboratory animals (Tapisso et al. 2009). In our study, deficient cultures presented a higher percentage of AC. In this sense, other reports showed that $\mathrm{Zn}$ deficiency induced apoptosis in different cell types such as fibroblasts, hepatocytes, $\mathrm{T}$ cell precursors, and glioma and testicular cells (Ho and Ames 2002; Ho et al. 2003; Bao and Knoell 2006; Yan et al. 2008; Yamaguchi et al. 2009).

Daily RDA provides a guide for the appropriate intake of nutrients for the prevention of diseases caused by deficiency or excess. Determining these extremes is important, but the biggest challenge in the prevention of developmental and degenerative diseases is defining the appropriate intakes of micronutrients to optimize cellular and organism performance at different life stages. Optimization of cellular function ultimately depends on the prevention of damage to the nuclear and mitochondrial genome (Fenech 2010). This becomes especially important in childhood, since the unique nutritional requirements of children make them unusually susceptible to inadequate nutrient intake.

Animal source foods are the major $\mathrm{Zn}$ source. Red meat, seafood, and fish make up the biggest contributions to $\mathrm{Zn}$ intake in the diets and present high bioavailability (Rosado 1998). In the last $30 \mathrm{yr}$, Argentina has changed the food consumption pattern, with a decrease in meat intake (Aguirre 2005). Moreover, a late incorporation of animal source food during the dietary complementation stage has been recorded in the child population, thereby exposing young children to an inadequate intake of $\mathrm{Zn}$ and irreversibly compromising their growth potential.

\section{Conclusions}

The results obtained in the present study suggest that in vitro supplementation of cultures with 80 and $180 \mu \mathrm{g} / \mathrm{dl} \mathrm{Zn}$ sulfate would avoid genomic instability. On the other hand, deficient cultures $(12 \mu \mathrm{g} / \mathrm{dl})$ and those presenting excess $\mathrm{Zn}(380 \mu \mathrm{g} / \mathrm{dl})$ would induce increased $\mathrm{AC}$ and $\mathrm{NC}$ percentages and cause higher DNA and chromosome damage. Likewise, the upper estimate of the physiological requirements recommended for 
children $(280 \mu \mathrm{g} / \mathrm{dl})$ would increase the cytostatic and cytotoxic effect as well as DNA and chromosome damage. These findings are important, since optimal mineral and vitamin levels are necessary to prevent DNA damage and, therefore, degenerative diseases such as cancer, cardiovascular disease, Alzheimer's, and premature aging.

We are aware of the limitations of our work, and future studies would be necessary to determine the adequate daily intake of this micronutrient. Although at first in vitro doseresponse studies would allow to evaluate the effect of $\mathrm{Zn}$ concentration on genetic damage and cytotoxicity, in vivo cross-sectional and interventional research is required to assess the association between nutrient intake and genetic damage. Similarly, future research on this subject should focus on the elucidation of the underlying mechanisms, whereby $\mathrm{Zn}$ would modulate DNA repair.

Acknowledgments This work was supported by the National Scientific and Technical Research Council-Argentina (Grant No. 0187) and La Plata National University (Grant No. 11/V212). The authors thank Adriana Di Maggio for careful manuscript correction and César E. Bianchi for technical assistance.

Compliance with ethical standards Written parental informed consent was obtained. This study was conducted according to the guidelines laid down in the Declaration of Helsinki and all procedures involving human subjects were approved by the Institutional Review Board of the Instituto de Desarrollo e Investigaciones Pediátricas (IDIP), La Plata Children Hospital, Buenos Aires, Argentina.

\section{References}

Aguirre P (2005) Características de las canastas de consumo de diferentes sectores de ingresos. En: Aguirre Patricia. Estrategias de consumo: qué comen los argentinos que comen. Buenos Aires: Ed Miño y Dávila; 69-106

Ames BN (1998) Micronutrients prevent cancer and delay ageing. Toxicol Lett 102/103:5-18

Bae SN, Kim J, Lee YS, Kim JD, Kim MY, Park LO (2007) Cytotoxic effect of zinc citrate compound on choriocarcinoma cell lines. Placenta 28:22-30

Bae SN, Lee YS, Kim MY, Kim JD, Park LO (2006) Antiproliferative and apoptotic effects of zinc-citrate compound (CIZAR(R)) on human epithelial ovarian cancer cell line, OVCAR-3. Gynecol Oncol 103:127-136

Bagchi D, Bagchi M, Stohs SJ (1997) Comparative in vitro oxygen radical scavenging ability of zinc methionine and selected zinc salts and antioxidants. Gen Pharmac 28(1):85-91

Bao S, Knoell DL (2006) Zinc modulates airway epithelium susceptibility to death receptor-mediated apoptosis. Am J Physiol Lung Cell Mol Physiol 290:L433-L441

Bray TM, Bettger WJ (1990) The physiological role of zinc as an antioxidant. Free Rad Biol Med 8:281-291

Chang KL, Hung TC, Hsieh BS, Chen YH, Chen TF, Cheng HL (2006) Zinc at pharmacologic concentrations affects cytokine expression and induces apoptosis of human peripheral blood mononuclear cells. Nutrition 22:465-474
Chung MJ, Walker PA, Brown RW, Hogstrand C (2005) ZINC-mediated gene expression offers protection against $\mathrm{H} 2 \mathrm{O} 2$-induced cytotoxicity. Toxicol Appl Pharmacol 205:225-236

Clegg MS, Hanna LA, Niles BJ, Momma TY, Keen CL (2005) Zinc deficiency induced cell death. IUBMB Life 57:661-669

Dreosti IE (2001) Zinc and the gene. Mutat Res 475:161-167

Feliu SM, Piñeiro A, López C, Slobodianik NH (2005) Valores de referencia de cobre, zinc y selenio en niños. Acta bioquím clín latinoam 39:459-462

Fenech M (2001) Recommended dietary allowances (RDAs) for genomic stability. Mutat Res 480-481:51-54

Fenech M (2002) Micronutrients and genomic stability: a new paradigm for recommended dietary allowances (RDAs). Food Chem Toxicol 40(8):1113-1117

Fenech M (2005) The genome health clinic and genome health nutrigenomics concepts: diagnosis and nutritional treatment of genome and epigenome damage on an individual basis. Mutagenesis 20(4):255-269

Fenech M (2007) Cytokinesis-block micronucleus cytome assay. Nat Protoc 5:1084-1104

Fenech M (2010) Dietary reference values of individual micronutrients and nutriomes for genome damage prevention: current status and a road map to the future. Am J Clin Nutr 91:1438S

Fenech M (2014) Nutriomes and personalised nutrition for DNA damage prevention, telomere integrity maintenance and cancer growth control. Cancer Treat Res 159:427-441

Fenech M, Ferguson LR (2001) Vitamins/minerals and genomic stability in humans. Mutat Res 475:1-6

Grandy G, Weisstaub G, López de Romaña D (2010) Deficiencia de hierro y zinc en niños. Rev Soc Bol Ped 49(1):25-31

Haase H, Rink L (2009) The immune system and the impact of zinc during aging. Immun Ageing 6:9

Hambidge KM (1989) Mild zinc deficiency in human subjects. In: Mills CF (ed) Zinc in human biology. Springer, London, pp 281-296

Ho E, Ames BN (2002) Low intracellular zinc induces oxidative DNA damage, disrupts p53 NFkappa B, and AP1 DNA binding, and affects DNA repair in a rat glioma cell line. Proc Natl Acad Sci U S A 99:16770-16775

Ho E, Courtemanche C, Ames BN (2003) Zinc deficiency induces oxidative DNA damage and increases p53 expression in human lung fibroblasts. J Nutr 133:2543-2548

Kimura M, Umegaki K, Higuchi M, Thomas P, Fenech M (2004) Methylenetetrahydrofolate reductase C677T polymorphism, folic acid and riboflavin are important determinants of genome stability in cultured human lymphocytes. J Nutr 134:48-56

Końca K, Lankoff A, Banasik A, Lisowska H, Kuszewski T, Góźdź S, Koza Z, Wojcik A (2003) A cross-platform public domain PC image-analysis program for the comet assay. Mutat Res 53:415-420

Lucchese TA, Breis AM, Rucker K, Bizarro VR, Mesquita Araújo LM, Gomes A, Paletti MT, Conceição de Jesus AL, Garcez Duarte M, Rosso Tenório Wanderley Rocha D, Arbex AK (2016) Diabetes, obesity and the nutrition transition in the Mercosur. Open Journal of Endocrine and Metabolic Diseases 6:28-37

Milne E, Greenop KR, Ramankutty P, Miller M, de Klerk NH, Armstrong BK, Almond T, O'Callaghan NJ, Fenech M (2015) Blood micronutrients and DNA damage in children. Mol Nutr Food Res 59:2057-2065

National Research Council (1989) Food and Nutrition Board: recommended daily dietary allowances, 10th edn. National Academy of Sciences, National Research Council, Washington

Nygaard SB, Larsen A, Knuhtsen A, Rungby J, Smidt K (2014) Effects of zinc supplementation and zinc chelation on in vitro $\beta$-cell function in INS-1E cells. BMC Research Notes 7:84

Olive P (1999) DNA damage and repair in individual cells: applications of the comet assay in radiobiology. Int J Radiat Biol 75:395 
Parry JM (1988) Studies upon the genetic effects of environmental chemicals: the coordinated research programme of the European Economic Community. Mutagenesis 3(2):105-136

Prasad AS (2013) Discovery of human zinc deficiency: its impact on human health and disease. Adv Nutr 4:176-190

Roohani N, Hurrell R, Kelishadi R, Schulin R (2013) Zinc and its importance for human health: an integrative review. J Res Med Sci 18(2): 144-157

Rosado JL (1998) Deficiencia de zinc y sus implicaciones funcionales. Salud Pública Mex 40:181-188

Sharif R, Thomas P, Zalewski P, Graham RD, Fenech M (2011) The effect of zinc sulphate and zinc carnosine on genome stability and cytotoxicity in the WIL2-NS human lymphoblastoid cell line. Mutat Res 720:22-33

Sharif R, Thomas P, Zalewskib P, Fenech M (2012) The role of zinc in genomic stability. Mutat Res 733:111-121

Sharif R, Thomas P, Zalewskib P, Fenech M (2015) Zinc supplementation influences genomic stability biomarkers, antioxidant activity, and zinc transporter genes in an elderly Australian population with low zinc status. Mol Nutr Food Res 59:1200-1212

Siklar Z, Tuna C, Dallar Y, Tanyer G (2003) Zinc deficiency: a contributing factor of short stature in growth hormone deficient children. J Trop Pediatr 49(3):187-188

Singh NP, McCoy MT, Tice RR, Schneider EL (1988) A simple technique for quantification of low levels of DNA damage in individual cells. Exp Cell Res 175:184-191

Sliwinski T, Czechowska A, Kolodziejczak M, Jajte J, WisniewskaJarosinska M, Blasiak J (2009) Zinc salts differentially modulate DNA damage in normal and cancer cells. Cell Biol Int 33:542-547

Song Y, Chung CS, Bruno RS, Traber MG, Brown KH, King JC, Ho E (2009a) Dietary zinc restriction and repletion affects DNA integrity in healthy men. Am J Clin Nutr 90:321-328

Song Y, Elias V, Loban A, Scrimgeour AG, Ho E (2009b) Marginal zinc deficiency increases oxidative DNA damage in the prostate after chronic exercise. Free Radic Biol Med 48:82-88

Song Y, Leonard SW, Traber MG, Ho E (2009c) Zinc deficiency affects DNA damage, oxidative stress, antioxidant defenses, and DNA repair in rats. J Nutr 139:1626-1631
Sunderman FW Jr (1995) The influence of zinc on apoptosis. Ann Clin Lab Sci 25:134-142

Szuster-Ciesielska A, Stachura A, Slotwinska M, Kaminska T, Sniezko R, Paduch R, Abramczyk D, Filar J, Kandefer-Szerszen M (2000) The inhibitory effect of zinc on cadmium-induced cell apoptosis and reactive oxygen species (ROS) production in cell cultures. Toxicology 145:159-171

Tapisso JT, Marques CC, Mathias L, Ramalhinho G (2009) Induction of micronuclei and sister chromatid exchange in bone-marrow cells and abnormalities in sperm of Algerian mice (Musspretus) exposed to cadmium, lead and zinc. Mutat Res 678:59-64

Tice R, Strauss G (1995) The single cell gel electrophoresis/comet assay: a potential tool for detecting radiation-induced DNA damage in humans. Stem Cells 13:207-214

Tice RR, Agurell E, Anderson D, Burlinson B, Hartmann A, Kobayashi H, Miyamae Y, Rojas E, Ryu J, Sasaki Y (2000) Single cell gel/ comet assay: guidelines for in vitro and in vivo genetic toxicology testing. Environ Mol Mutagen 35:206-221

Varea A, Disalvo L, González H (2006) Repercusión de las deficiencias de micronutrientes en salud pública. Ludovica Pediátrica VII:10-15

Wise SS, Holmes AL, Qin Q, Xie H, Katsifis SP, Thompson WD, Wise JP Sr (2010) Comparative genotoxicity and cytotoxicity of four hexavalent chromium compounds in human bronchial cells. Chem Res Toxicol 23:365-372

Wu J, Lyons GH, Graham RD, Fenech M (2009) The effect of selenium, as selenomethionine, on genome stability and cytotoxicity in human lymphocytes measured using the cytokinesis-block micronucleus cytome assay. Mutagenesis 24:225-232

Xie H, Holmes AL, Young JL, Qin Q, Joyce K, Pelsue SC, Peng C, Wise SS, Jeevarajan AS, Wallace WT, Hammond D, Wise JP Sr (2009) Zinc chromate induces chromosome instability and DNA double strand breaks in human lung cells. Toxicol Appl Pharmacol 234: 293-299

Yamaguchi S, Miura C, Kikuchi K, Celino FT, Agusa T, Tanabe S, Miura $\mathrm{T}$ (2009) Zinc is an essential trace element for spermatogenesis. Proc Natl Acad Sci U S A 106:10859-10864

Yan M, Song Y, Wong CP, Hardin K, Ho E (2008) Zinc deficiency alters DNA damage response genes in normal human prostate epithelial cells. J Nutr 138:667-673 